J. Lake Sci.(湖泊科学), $2018, \mathbf{3 0}(2): 417-430$

DOI 10. 18307/2018. 0213

(c) 2018 by Journal of Lake Sciences

\title{
神农架大九湖湿地浮游植物群落结构特征及营养状态评价”
}

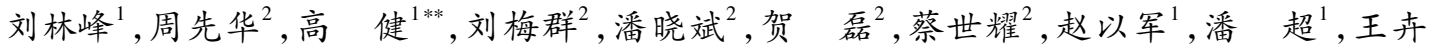 \\ 君 $^{1}$, 张佳敏 $^{1}$, 叶有旺 $^{1}$, 刘 伟 ${ }^{1}$ \\ (1: 湖北工业大学河湖生态修复与藻类利用湖北省重点实验室,土木建筑与环境学院,武汉 430068) \\ $(2$ : 湖北十堰市水文水资源勘测局, 十堰 442000)
}

\begin{abstract}
摘 要: 大九湖湿地是南水北调中线工程的重要水源涵养地之一. 为了解实施生态修复工程后浮游植物群落结构特征及 水质营养状态, 于 2014 年 11 月- 2015 年 9 月进行了 3 次采样调查, 综合营养状态指数表明水质处于中营养和轻度富营 养化之间, 水质富营化水平沿水流方向呈降低趋势; 共采集浮游植物 8 门 129 种, 11 月优势种为绿藻门的四尾栅藻 (Scenedesmus quadricauda) 和硅藻门的颗粒直链藻 (Melosira granulata)、短缝藻 (Eunotia sp.);5 月优势种为蓝藻门的纤细 席藻 (Phormidium tenue)、绿藻门的四尾栅藻 (Scenedesmus quadricauda) 和球衣藻 (Chlamydomonas globosa Snow)、硅藻门的 短线脆杆藻 (Fragilaria brevistriata); 9 月优势种为蓝藻门的拟柱狍藻 (Cylindrospermopsis raciborskii) 、小形色球藻 (Chroococcus minor) 和泽丝藻 (Limnothrix redekei), 优势种主要为中污带指示种. 尣余分析表明总磷和总氮浓度对浮游植 物丰度变化有显著影响, 温度和总磷浓度对浮游植物生物量有显著影响, 蓝藻门和绿藻门的丰度和生物量均与总磷浓度 呈正相关.
\end{abstract}

关键词: 神农架; 大九湖湿地;浮游植物; 群落结构;营养状态

\section{Phytoplankton community structure and trophic status evaluation in Dajiuhu wetland of Shennongjia Alpine}

LIU Linfeng $^{1}$, ZHOU Xianhua $^{2}$, GAO Jian $^{1 * *}$, LIU Meiqun ${ }^{2}$, PAN Xiaobin $^{2}$, HE Lei $^{2}$, CAI Shiyao $^{2}$, ZHAO Yijun $^{1}$, PAN Chao ${ }^{1}$, WANG Huijun ${ }^{1}$, ZHANG Jiamin ${ }^{1}$, YE Youwang ${ }^{1} \&$ LIU Wei ${ }^{1}$

(1: Key Laboratory of Ecological Remediation of Lakes and Rivers and Algal Utilization of Hubei Province, School of Civil and Environment, Hubei University of Technology, Wuhan 430068, P.R.China)

(2: Hydrology and Water Resources Survey Bureau of Shiyan, Shiyan 442000, P.R.China)

Abstract: Dajiuhu wetland is a rare subtropical alpine in the central China. Dajiuhu wetland is the source of the Du River, a firstgrade tributary of the Han River, and the wetland also serves as one of the important water conservation area of the middle routes of South-to-North Water Diversion Project. The human activities such as ditches digging, holes dredging and bog draining have led to severe degradation of ecological function and the shrinking of lake surface area in Dajiuhu wetland since 1986. After the implementation of 'the Dajiuhu wetland protection and ecological restoration project' from 2005 until present, we conducted a field survey on the phytoplankton community and lake trophic status from November 2014 to September 2015 to reveal the status quo post the restoration project. Trophic status indices showed the water quality was between mesotrophy and light eutrophication. The water eutrophication level decreased along the water flow direction. A total of 129 phytoplankton species belonging 8 phyla were observed. Scenedesmus quadricauda, Melosira granulate and Eunotia sp. were the common dominant species in November 2014, and Phormidium tenue, Chlamydomonas globosa Snow, Scenedesmus quadricauda and Fragilaria brevistriata in May 2015; Limnothrix re-

* 国家自然科学基金项目 (31500378)、湖北省水利重点科研项目 (HBSLKY201719)、湖北省科技支撑计划项目 (2015BCH329)、湖北工业大学高层次人才科研启动金 (337301) 和河湖生态修复与藻类利用湖北省重点实验室开 放基金项目 (HHKF201506) 联合资助. 2017-05-22 收稿; 2017-07-05 收修改稿. 刘林峰(1991 ), 男, 硕士研究 生; E-mail: 528449870@qq.com.

** 通信作者; E-mail: jgao13@ hotmail.com. 
dekei, Cylindrospermopsis raciborskii, and Chroococcus minor in September 2015. All the dominant species were $\alpha$ or $\beta$-mesosaprobity species. Redundancy analyses indicated that total phosphorus and total nitrogen were the key drivers behind this difference of the phytoplankton abundance, while water temperature and total phosphorus showed significant effects on phytoplankton biomass. Redundancy analyses further showed a positive relationship between total phosphorus and the abundance (and biomass) of Cyanophyta or Chlorophya.

Keywords: Shennongjia Alpine; Dajiuhu wetland; phytoplankton; community structure; trophic status

浮游植物是水生态系统敞水区的主要初级生产者, 其种类组成、数量及多样性对水环境变化反应敏 感 ${ }^{[1-3]}$, 常作为评估水质和水生态状况的重要指示生物指标 ${ }^{[4-5]}$. 浮游植物优势种在未受污染的水体中往往 表现多样性高, 且以硅藻为主, 同时有少量蓝藻和绿藻; 而受污染水体中浮游植物多样性明显减少, 群落组 成也发生变化, 硅藻不再占优势, 各种蓝藻、绿藻大量繁殖, 成为优势种, 因此在不同的污水带中有不同的指 示藻类出现 ${ }^{[6]}$. 浮游植物如蓝藻门的部分种类在生长旺盛时, 能够聚集堆积在水面, 散发出难闻的气味, 影 响生态景观, 破坏水生态系统平衡, 且当藻细胞衰亡后, 体内毒素及其衍生物会释放到水体中, 对人畜饮用 水安全构成严重威胁 ${ }^{[7]}$. 因此, 世界卫生组织 (WHO $)^{[8]}$ 、欧盟水框架指令 (EUWFD $)^{[9]}$ 和我国环境保护部、 水利部均把浮游植物监测纳人湖泊、河流和水库的监测体系中, 尤其在饮用水源地 ${ }^{[10-12]}$.

大九湖湿地属典型的亚高山沼泽型湿地湖泊, 是汉江最大支流——堵河的发源地和 “南水北调” 中线工 程的重要水源涵养地之一, 也是世界著名的人与生物圈保护区和生物多样性保护示范点的缓冲区 ${ }^{[13]}$. 然 而, 大九湖湿地曾经历大规模开层种植、养殖等活动, 导致生态环境退化、水质下降、湖泊水面消失和湿地生 态系统向陆生生态系统演化,湿地生态系统曾被侵蚀殆尽 ${ }^{[13-15]}$. 2005 年启动,2008 年开始实施的 “大九湖湿 地保护与恢复及公园建设工程”, 对大九湖湿地进行平沟还湖、退耕还泽还草、植被恢复等工程, 恢复了9 个 子湖湖面 ${ }^{[14]}$. 目前, 尽管大九湖湿地的生态环境有所改善, 但其水体透明度仍不高. 由于大九湖湿地的水质 和水生态资料均较缺乏, 导致目前对大九湖湿地营养状况认识不足,保护目标缺乏针对性.

本研究于 2014-2015 年对大九湖湿地 9 个子湖的浮游植物群落结构及环境因子首次开展了较系统地 调查, 分析了大九湖湿地浮游植物种类优势种组成及其对水生态系统潜在的指示效应, 并分析了影响浮游 植物种类组成的关键环境因子. 本研究将为合理评估大九湖湿地水质营养状况和实施有针对性的生态保护 措施保障水源涵养地水质安全提供科学依据, 也将为大九湖湿地的长期保护与治理增添水生态基础资料.

\section{1 材料与方法}

\section{1 研究地点和采样时间}

大九湖湿地 $\left(31^{\circ} 28^{\prime} \sim 31^{\circ} 30^{\prime} \mathrm{N}, 109^{\circ} 58^{\prime} \sim 110^{\circ} 2^{\prime} \mathrm{E}\right)$ 位于湖北省神农架的最西端, 海拔 $1770 \sim 1800 \mathrm{~m}$, 位 于西部高山平原与东部丘陵平原、亚热带和北温带的交界部位, 是一个高山湿地湖泊 ${ }^{[16]}$. 大九湖地区受季 风控制, 属于过渡性亚热带一暖温带山地季风气候. 据大九湖站的多年气象记录, 年均降水量为 $1535 \mathrm{~mm}$, 年 均温度 $7.2^{\circ} \mathrm{C}, 7$ 月平均温度 $17.1^{\circ} \mathrm{C}, 1$ 月平均温度 $-2.4^{\circ} \mathrm{C}^{[17]}$.

9 个子湖地势由南向北逐渐降低, 并由沟渠串联在一起, 水流流向是从 D1 号湖到 D9 号湖, 最后经落水 孔进人地下河 (图 1). 每个子湖又可从其周边接纳雨水和少量居民生活污水. 采样期间, 大九湖周边居民 (包括游客) 主要集中在 D1 号湖和 D2 号湖旁边 (采样期间周边居民尚未开始搬迁, 旅游季游客主要住宿在 D1 号湖旁边的大九湖镇), 部分污水就近排放.

采样时间为 2014 年 11 月 (水温约 $8.5^{\circ} \mathrm{C}$, 枯水期)、 2015 年 5 月 (水温约 $17.1^{\circ} \mathrm{C}$, 平水期) 和 2015 年 9 月 (水温约 $20.3^{\circ} \mathrm{C}$, 丰水期). 由于大九湖冬季大雪封山, 湖面结冰, 因此未在冬季采样. 大九湖 9 个湖泊面积从 D1 D9 号湖分别约为 $18.2 、 11.0 、 4.2 、 7.4 、 26.0 、 1.5 、 4.0 、 3.8$ 和 $2.8 \mathrm{hm}^{2}$, 面积主要指水面覆盖的区域, 不包含 周边的湿生植物生长区域,水深范围约为 $1.0 \sim 2.5 \mathrm{~m}^{[18]}$.

\section{2 样本采集及分析}

在各个子湖湖中心区域监测水质理化指标和采集浮游植物样品.

透明度 (SD) 采用塞氏盘 (Secchi-disk) 现场测定. 水温 (WT)、pH 值和溶解氧 ( DO) 等参数采用 Hydro lab DS5 多参仪 (美国) 现场测定. 


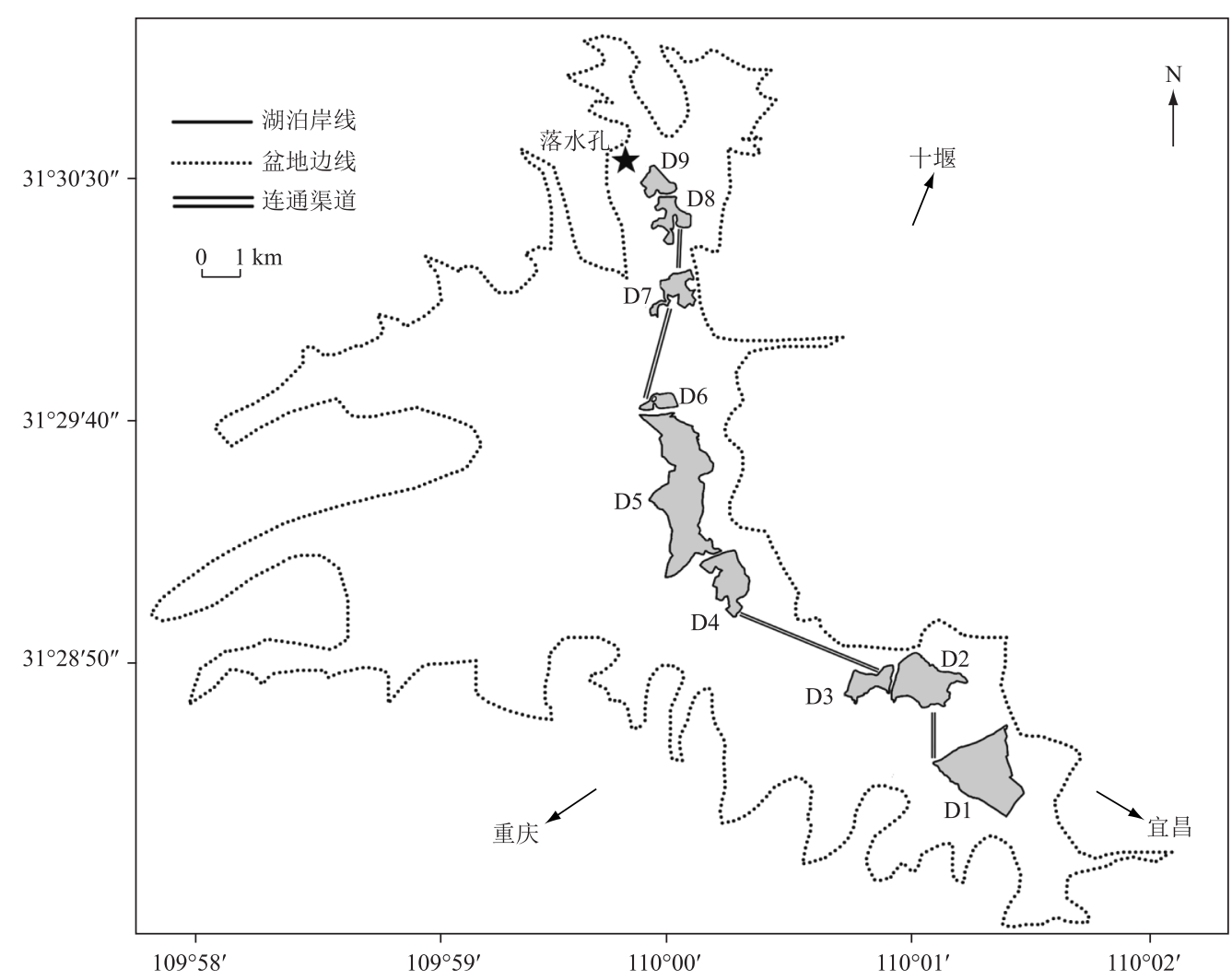

图 1 大九湖湿地采样点 (D1 D9 分别代表大九湖湿地 9 个子湖, 水流流向是从 D1 流向 D9)

Fig.1 Location of sampling sites in Dajiuhu wetland, which is divided into 9 basins by embankments

( D1 to D9 indicate nine sub-lakes, the direction of water flow is from D1 to D9)

用 $5 \mathrm{~L}$ 有机玻璃采水器采集水表面下 $0.5 \mathrm{~m}$ 处水样, 在湖中心区域随机采集 4 次, 共计 $20 \mathrm{~L}$ 水样放置在 预先用湖水洗净的塑料桶内, 混合后取约 $2.5 \mathrm{~L}$ 水样低温保存, 带回实验室分析水质. 总氮 $(\mathrm{TN}) 、$ 总磷 $(\mathrm{TP})$ 和高锰酸盐指数 $\left(\mathrm{COD}_{\mathrm{Mn}}\right)$ 等水质指标的测定方法依据《水和废水监测分析方法》第四版 ${ }^{[19]}$.

浮游植物样品是取上述混合水样 $1 \mathrm{~L}$ 置于广口塑料瓶中用于浮游植物鉴定, 现场加人约水样体积 $1 \%$ 的 鲁哥试剂固定, 带回实验室静置 $24 \mathrm{~h}$ 以上后沉淀、浓缩并在尼康倒置显微镜下计数镜检, 浮游植物鉴定参照 《中国淡水藻类: 系统、分类及生态》 ${ }^{[20]}$, 浮游植物尽量鉴定到种, 其中部分硅藻鉴定到属. 计数方法为目镜 视野法, 用 $0.1 \mathrm{ml}$ 浮游植物计数框在 $10 \times 40$ 倍光学显微镜下进行,一般计数 50 个视野, 使所得到的细胞数 在 300 以上, 每个样品至少计数 2 片, 对量小而个体大的种类在 $10 \times 10$ 倍下全片计数. 根据浓缩倍数换算为 每升水样中的细胞数 ( cells/L), 即浮游植物的丰度. 由于浮游植物的比重接近 1 , 故可以直接由浮游植物的 体积换算为生物量 (鲜重), 即生物量为浮游植物的丰度乘以各自的平均体积 ${ }^{[21]}$, 单位为 $\mathrm{mg} / \mathrm{L}$.

\section{3 数据处理及分析}

1.3.1 综合营养状态指数评价 参考湖泊富营养化评价方法及分级标准 ${ }^{[22]}$, 依据 Chl.a、TP、TN、SD 和 $\mathrm{COD}_{\mathrm{Mn}}$ 的测定结果, 运用综合营养状态指数法对大九湖湿地生态系统健康状况进行评价. 综合营养状态指数计算 公式为:

$$
T L I\left(\sum\right)=\sum W_{j} \cdot T L I(j)
$$

式中, $T L I\left(\sum\right)$ 表示综合营养状态指数; $T L I(j)$ 代表第 $j$ 种参数的营养状态参数; $W_{j}$ 为第 $j$ 种参数的营养状态 指数的相关权重, 详细计算公式见参考文献 [22]. 
参考《中国水资源公报》 ${ }^{[23]}$ 中湖泊、水库富营养化评分与分类标准将湖泊营养状态分成 5 级, 同一营养 状态下, 指数值越高, 其营养程度越严重:贫营养, $T L I\left(\sum\right)<30$; 中营养, $30 \leqslant T L I\left(\sum\right) \leqslant 50$; 轻度富营养, $50<$ $T L I\left(\sum\right) \leqslant 60$, 中度富营养: $60<T L I\left(\sum\right) \leqslant 70$; 重度富营养, $T L I\left(\sum\right)>70$.

1.3.2 优势种 浮游植物优势种根据 Mcnaughton 优势度指数 $(Y)$ 来确定 ${ }^{[24]}$ :

$$
Y=\frac{n_{i}}{N} \cdot f_{i}
$$

式中, $n_{i}$ 为第 $i$ 种的个体数, $N$ 为所有种类总个体数, $f_{i}$ 为出现频率, $Y$ 值 $\geqslant 0.02$ 的种类视为优势种. 优势种的 变化在一定程度上可直接反映水体污染程度和环境条件的改变 ${ }^{[6,25]}$. 优势种对水环境的指示分类参照 $\mathrm{B}$. 福 迪提出的指示生物法 ${ }^{[6]}$.

1.3.3 生物多样性分析 浮游植物群落多样性分析采用 Shannon-Wiener 多样性指数 $\left(H^{\prime}\right)^{[26]}$ 和 Margalef 物种丰 富度指数 $(D)^{[27]}$. $H^{\prime}$ 值处于 $0 \sim 1$ 之间表示水质严重污染, $1 \sim 2$ 之间表示水质为 $\alpha$-中污型, $2 \sim 3$ 之间表示水质 为 $\beta$-中污型, $>3$ 表示水体清洁. $D$ 值越高, 表示污染越轻; $D$ 值越低, 表示污染越严重. $D$ 值处于 $0 \sim 1$ 之间表示 水质状况为多污型, $1 \sim 2$ 之间表示水质为 $\alpha$-中污型, $2 \sim 3$ 之间表示水质为 $\beta$-中污型, $3 \sim 4$ 之间为寡污型, $>4$ 表 示水质清洁.

大九湖水体各理化指标沿水流方向变化趋势通过 SPSS Statistics 22.0 进行 Pearson 线性相关分析, $P<$ 0.05 表示有显著差异, $P<0.01$ 表示有极显著差异. 大九湖浮游植物与环境因子关系采用多元分析进行. 浮 游植物运用降趋势对应分析 (DCA) 确定浮游植物丰度是适合线性分析还是单峰梯度分析. 本研究中最大轴 小于 3 , 因此采用圥余分析 $(\mathrm{RDA})^{[28]}$ 探讨大九湖湿地浮游植物丰度与环境因子 (包括 WT、DO、 $\mathrm{pH} 、 \mathrm{TN} 、 \mathrm{TP}$ 和 $\mathrm{SD}$, 而 $\mathrm{COD}_{\mathrm{Mn}}$ 值由于受浮游植物浓度的影响而被排除在外) 的关系. 为了获得正态分布数据, 将浮游植物 和环境因子 (除 $\mathrm{pH})$ 均进行 $\ln (x+1)$ 转换. DCA 和 RDA 分析通过 Canoco 4.5 软件进行.

\section{2 结果与分析}

\section{1 大九湖湿地水体理化特征和变化规律}

2014 年 11 月大九湖的 WT 均值为 $8.5^{\circ} \mathrm{C}, 2015$ 年 5 月为 $17.1^{\circ} \mathrm{C}, 2015$ 年 9 月为 $20.3^{\circ} \mathrm{C}$; DO 浓度在 11 月 均值为 $9.5 \mathrm{mg} / \mathrm{L}, 5$ 月为 $8.9 \mathrm{mg} / \mathrm{L}, 9$ 月为 $7.1 \mathrm{mg} / \mathrm{L} ; \mathrm{pH}$ 值在 11 月均值为 7.9,5 月为 8.6,9 月为 8.0(表 1).

大九湖 $\mathrm{TN}$ 浓度均值范围为 $0.8 \sim 0.9 \mathrm{mg} / \mathrm{L}$; TP 浓度均值为 $0.03 \sim 0.05 \mathrm{mg} / \mathrm{L}$; SD 均值范围为 $32 \sim 102 \mathrm{~cm}$, 11 月 $\mathrm{SD}$ 最高, 9 月最低; Chl.a 浓度均值范围为 $28.6 \sim 44.8 \mu \mathrm{g} / \mathrm{L}, 11$ 月最低, 9 月最高; $\mathrm{COD}_{\mathrm{Mn}}$ 均值 11 月最 低, 5 月和 9 月值接近 (表 1). TLI 均值范围在 $47.9 \sim 49.6$ 之间 (表 1), 部分子湖营养状态指数值在 $50 \sim 60$ 之 间(图 2), 表明大九湖湿地水质处于中营养和轻度富营养水平之间.

大九湖湿地水体各理化指标沿水流方向呈下降趋势, 其中 11 月 TP 浓度、Chl.a 浓度、TLI 沿水流方向显 著下降 $(P<0.05), 5$ 月 TN 、TP 浓度沿水流方向显著下降 $(P<0.01), 9$ 月 SD 显著下降 $(P<0.05)$ (图 2), 但 SD 均值在 9 月最低(表 1$)$.

表 1 大九湖湿地不同季节水质理化特征

Tab.1 Physicochemical characteristics of Dajiuhu wetland among three seasons

\begin{tabular}{lccc}
\hline 理化因子 & 2014 年 11 月 & 2015 年 5 月 & 2015 年 9 月 \\
\hline $\mathrm{WT} /{ }^{\circ} \mathrm{C}$ & $8.5(6.7 \sim 10.7)$ & $17.1(14.8 \sim 18.6)$ & $20.3(18.4 \sim 22.0)$ \\
$\mathrm{DO} /(\mathrm{mg} / \mathrm{L})$ & $9.5(8.7 \sim 10.7)$ & $8.9(7.2 \sim 10.1)$ & $7.1(6.1 \sim 8.8)$ \\
$\mathrm{pH}$ & $7.9(7.3 \sim 8.6)$ & $8.6(7.8 \sim 9.4)$ & $8.0(7.4 \sim 8.9)$ \\
$\mathrm{TN} /(\mathrm{mg} / \mathrm{L})$ & $0.8(0.5 \sim 1.8)$ & $0.9(0.5 \sim 1.4)$ & $0.8(0.6 \sim 1.3)$ \\
$\mathrm{TP} /(\mathrm{mg} / \mathrm{L})$ & $0.03(0.01 \sim 0.05)$ & $0.03(0.01 \sim 0.07)$ & $0.05(0.03 \sim 0.08)$ \\
$\mathrm{SD} / \mathrm{cm}$ & $102(70 \sim 180)$ & $44(30 \sim 110)$ & $32(20 \sim 60)$ \\
$\mathrm{Chl} . \mathrm{a} /(\mu \mathrm{g} / \mathrm{L})$ & $28.6(10.8 \sim 52.9)$ & $42.7(7.9 \sim 127.2)$ & $44.8(24.8 \sim 95.5)$ \\
$\mathrm{COD}$ & $5.6(4.4 \sim 6.4)$ & $5.4(3.7 \sim 6.5)$ \\
$T L I$ & $4.0(2.5 \sim 4.9)$ & $49.5(38.3 \sim 60.4)$ & $49.6(46.1 \sim 56.8)$ \\
\hline
\end{tabular}




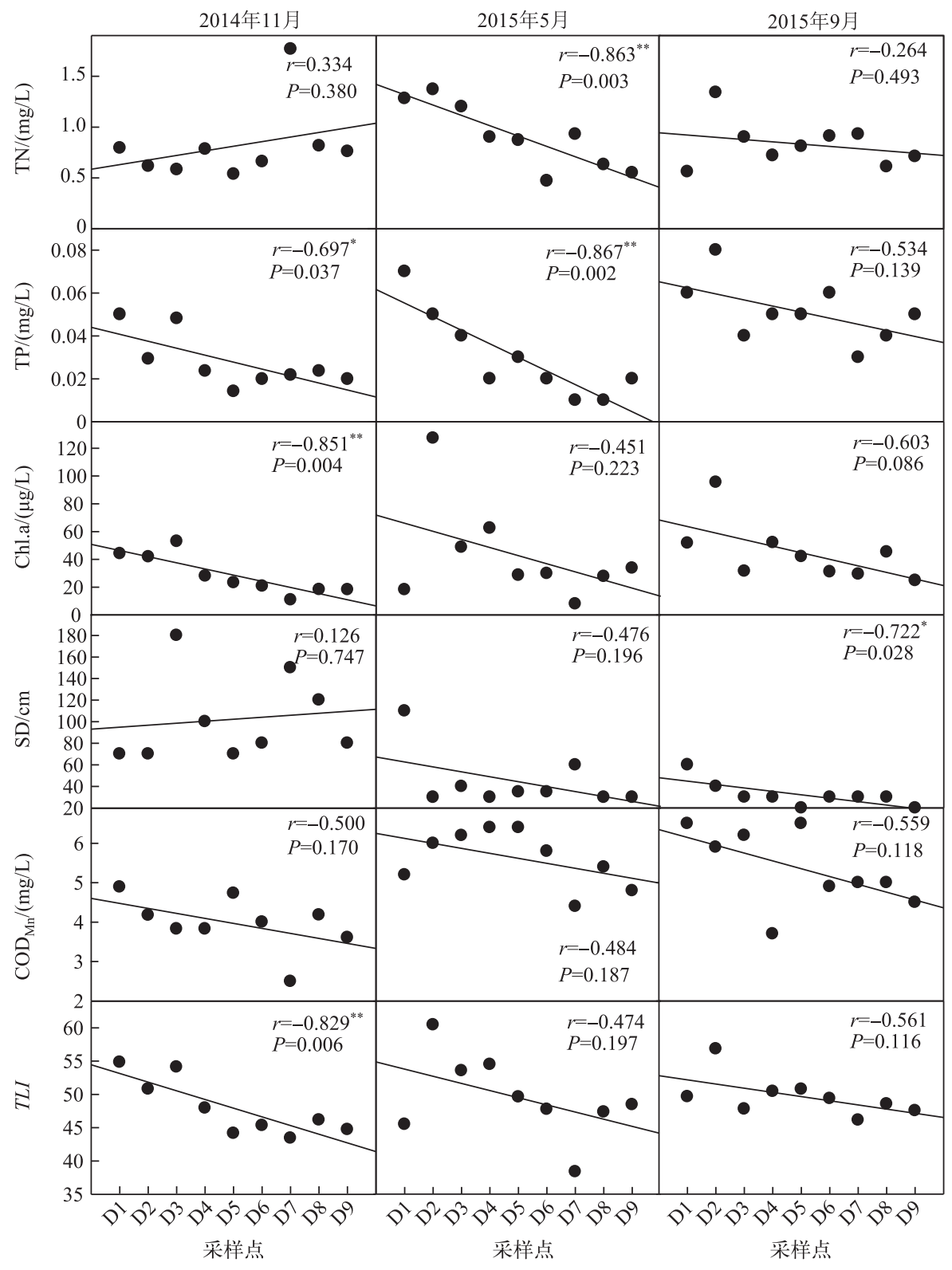

图 2 大九湖湿地各子湖理化因子特征和沿水流方向变化趋势

Fig.2 Physicochemical characteristics of each sub-lake in Dajiuhu wetland and trend analysis along water flow direction

\section{2 大九湖湿地浮游植物特征}

2.2.1 浮游植物种类组成及优势种 大九湖湿地 3 次调查中共采集到浮游植物 129 种,其中蓝藻门 15 种、绿 藻门 61 种、硅藻门 32 种、裸藻门 13 种、隐藻门 3 种、甲藻门 2 种、金藻门 2 种和黄藻门 1 种. 从季节来看, 11 月采集到浮游植物 51 种, 优势种是绿藻门的四尾柵藻和硅藻门的颗粒直链藻和短缝藻; 5 月采集到浮游植 物 55 种, 优势种为蓝藻门的小席藻、绿藻门的四尾栅藻和球衣藻、硅藻门的短线脆杆藻; 9 月采集到浮游植 物 89 种, 优势种为蓝藻门的拟柱孢藻、小形色球藻和泽丝藻 (表 2 ); 优势种主要是 $\alpha$-中污带或 $\beta$-中污带指 
示种.

表 2 大九湖湿地不同季节浮游植物优势种组成和优势度值

Tab.2 Composition of phytoplankton dominant species and its $Y$ values in three seasons of Dajiuhu wetland

\begin{tabular}{|c|c|c|c|c|c|}
\hline \multirow{2}{*}{ 浮游植物 } & \multirow{2}{*}{ 优势种 } & \multirow{2}{*}{$\begin{array}{c}\text { 污染 } \\
\text { 类型 }{ }^{1)}\end{array}$} & \multicolumn{3}{|c|}{$Y$ 值 } \\
\hline & & & 11 月 & 5 月 & 9 月 \\
\hline \multirow[t]{4}{*}{ 蓝藻门 } & 小席藻 Phormidium tenue & $\alpha$-中污带 & - & 0.14 & - \\
\hline & 拟柱狍藻 Cylindrospermopsis raciborskii & $*$ & - & - & 0.06 \\
\hline & 小形色球藻 Chroococcus minor & * & - & - & 0.03 \\
\hline & 泽丝藻 Limnothrix redekei & * & - & - & 0.18 \\
\hline \multirow[t]{2}{*}{ 绿藻门 } & 四尾栅藻 Scenedesmus quadricauda & $\alpha$-中污带 & 0.13 & 0.07 & - \\
\hline & 球衣藻 Chlamydomonas globosa Snow & $\beta$-中污染 & - & 0.11 & - \\
\hline \multirow[t]{3}{*}{ 硅藻门 } & 颗粒直链藻 Melosira granulata & $\beta$-中污染 & 0.07 & - & - \\
\hline & 短缝藻 Eunotia sp. & $\alpha$-中污带 & 0.06 & - & - \\
\hline & 短线脆杆藻 Fragilaria brevistriata & $\beta$-中污带 & - & 0.04 & - \\
\hline
\end{tabular}

1) 0 :寡污; $0-\beta$ : 寡污 $-\beta$ 中污; $\beta: \beta$-中污; $\beta-\alpha: \beta-\alpha$ 中污; $\alpha: \alpha$-中污;一表示未见该优势种; $*$ 表示污染类型不确定.

2.2.2 浮游植物丰度和生物量 大九湖湿地各子湖 11 月浮游植物丰度在 $0.09 \times 10^{6} \sim 13.65 \times 10^{6} \mathrm{cells} / \mathrm{L}$ 之间, D1 子湖丰度最高, 硅藻门的短缝藻为最优势种, 丰度占 $74.6 \%$; D 7 湖丰度最低, 硅藻门的颗粒直链藻为最 优势种, 丰度占 $74.8 \% .5$ 月浮游植物丰度在 $1.20 \times 10^{6} \sim 26.20 \times 10^{6} \mathrm{cells} / \mathrm{L}$ 之间, D1 子湖丰度最高, 蓝藻门的 小席藻为最优势种, 占 $81.6 \%$; D7 子湖最低, 硅藻门的颗粒直链藻为最优势种, 占 $50 \% .9$ 月浮游植物丰度在 $15.25 \times 10^{6} \sim 717.58 \times 10^{6}$ cells $/ \mathrm{L}$ 之间, D1 子湖丰度最高, 蓝藻门的泽丝藻为最优势种, 占 $69.4 \%$; D6 子湖最 低, 硅藻门的具槽直链藻为最优势种, 占 $35.1 \%$ (图 3a). 浮游植物丰度沿水流方向在 3 次采样时均呈降低趋 势,但方差分析结果不显著(图 3a).

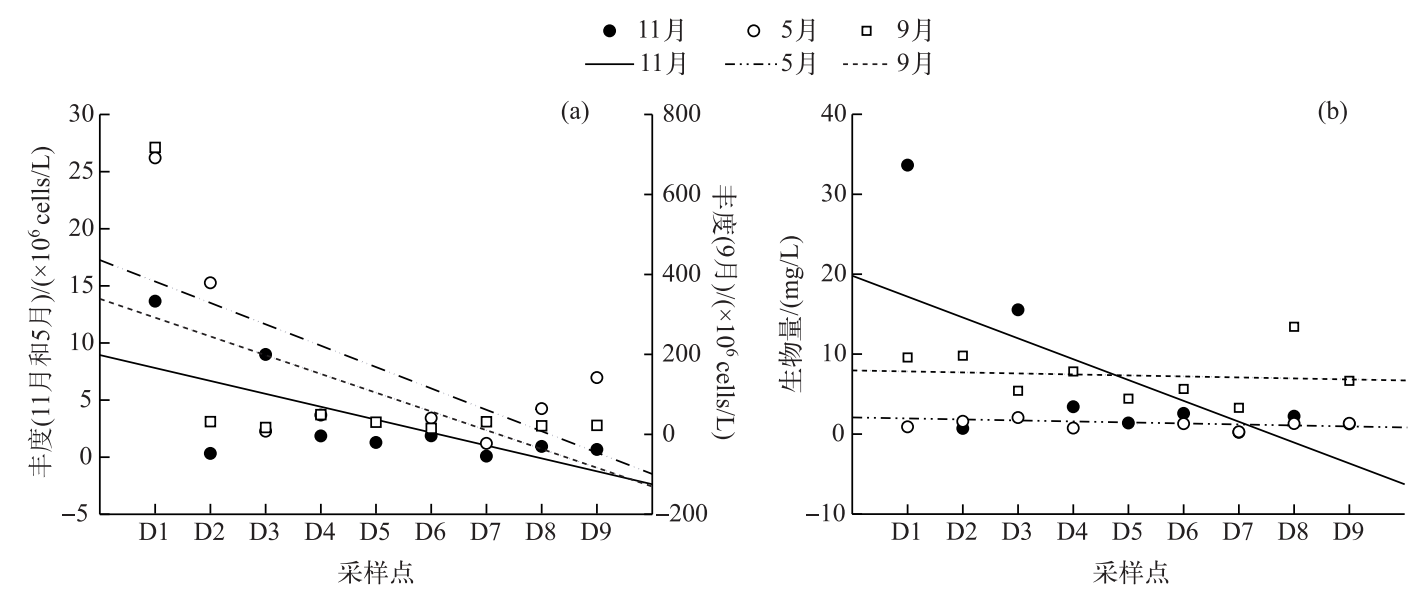

图 3 大九湖湿地浮游植物丰度 $(\mathrm{a})$ 和生物量 $(\mathrm{b})$ 及沿水流方向的变化趋势

Fig.3 Variations of phytoplankton abundance(a) and biomass(b) among different sub-lakes in Dajiuhu wetland and trend analysis along water flow direction

大九湖湿地各子湖 11 月浮游植物生物量在 $0.19 \sim 33.63 \mathrm{mg} / \mathrm{L}$ 之间 (图 3b), D1 子湖生物量最高, 硅藻 门的短缝藻占 $90.8 \% ; \mathrm{D} 7$ 子湖生物量最低, 颗粒直链藻占 $67.2 \% .5$ 月浮游植物生物量在 $0.27 \sim 2.05 \mathrm{mg} / \mathrm{L}$ 之 间, D3 子湖生物量最高, 硅藻门的双头辐节藻占 $72.1 \%$; D7 子湖生物量最低, 颗粒直链藻占 $54.5 \% .9$ 月浮游 植物生物量在 3.28 13.42 mg/L 之间, D8 子湖生物量最高, 甲藻门的飞燕角甲藻占 $40.7 \%$; D7 子湖生物量 最低, 黄藻门的黄丝藻占 $34.1 \%$ ( 图 $3 \mathrm{~b}$ ). 在 11 月, 浮游植物生物量沿水流方向有明显降低趋势, 而在 5 月和 
9 月沿水流方向无明显变化(图 3b).

大九湖湿地浮游植物比例分析结果表明 (图 4), 11 月 9 个子湖丰度均以硅藻门和绿藻门为主, 而生物 量硅藻门占绝对优势; 5 月 D1 子湖丰度中蓝藻门占 $87.9 \%, \mathrm{D} 2 、 \mathrm{D} 3$ 和 D4 子湖绿藻门比例超过 $50 \%$, D6 子湖 中蓝藻门、绿藻门、硅藻门和金藻门比例均在 $20 \%$ 以上, 而 D7、D8 和 D9 子湖以绿藻门和硅藻门为主; 5 月各 子湖生物量硅藻门占优势. 9 月 D1 D9 子湖丰度以蓝藻门和绿藻门为主; 从生物量结果来看, D1 子湖生物 量蓝藻门占 $80.6 \%$, D4 子湖蓝藻门占 $38.3 \%$, 而 D2、D6、D9 子湖以硅藻门为主, D3 子湖裸藻门占 $37.1 \%, \mathrm{D} 5$ 子湖黄藻门占 $49.4 \%, \mathrm{D} 8$ 子湖硅藻门和甲藻门分别占 $34.0 \%$ 和 $40.7 \%$.

从季节上来看, 从 2014 年 11 月- 2015 年 9 月, 蓝藻门和绿藻门的丰度和生物量呈增加趋势, 而硅藻门 的生物量呈减少趋势 (图 4).

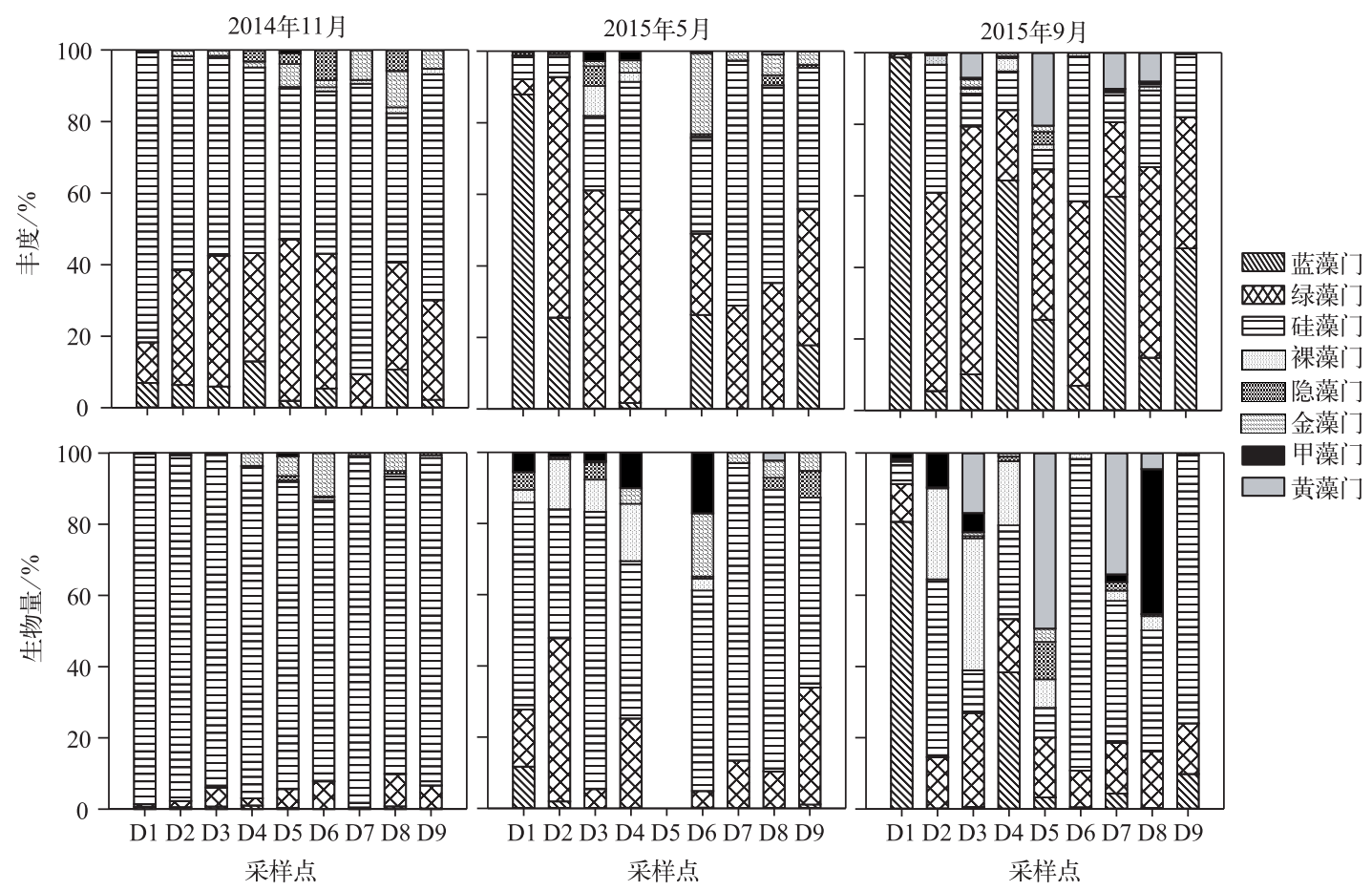

图 4 大九湖湿地浮游植物各门丰度和生物量占比

Fig.4 Percentage of abundance and biomass of each phylum phytoplankton in Dajiuhu wetland

2.2.3 浮游植物多样性指数 采样期间大九湖 $H^{\prime}$ 值主要集中在 $1.0 \sim 3.0$ 之间 (图 5a), 指示水质处于 $\alpha$-中污 染; $D$ 值 11 月在 3.0 6.0 之间 (图 5b), 指示水质处于臭污染, 5 月和 9 月指数值处于 $1.0 \sim 2.0$ 之间, 表明水 质处于 $\alpha$-中污染. 从 2 个多样性指数的水质生物学评价总体情况来看, 浮游植物多样性指数反映的水质处 于中度污染状态 (图 5). $H^{\prime}$ 值沿水流方向有增高趋势, 而 $D$ 值变化趋势不明显 (图 5).

\section{3 大九湖湿地浮游植物与环境因子关系}

通过 RDA 分析浮游植物各门丰度和生物量分别与环境因子之间的关系. 基于丰度, 主成分轴 1 和轴 2 特征值分别是 0.264 和 0.136 , 即前 2 个轴共解释了 $40.0 \%$ 的浮游植物各门的丰度变化 (图 6a). 主成分轴 1 和轴 2 的物种与环境因子相关性分别为 $82.1 \%$ 和 $77.1 \%$, 2 轴累计百分比变化率为 $81.3 \%$, 表明前 2 个轴的 物种与环境因子相关性高. RDA 蒙特卡罗检验前向选择检验表明, TP 和 TN 浓度对浮游植物丰度变化有显 著影响 (图 6a). 这 2 个变量共解释了 $34.0 \%$ (分别为 $25.0 \%$ 和 $9.0 \%$ ) (图 6a). TP 浓度与金藻门丰度呈负相 关, 而与其他各门藻丰度呈正相关; 而 $\mathrm{TN}$ 浓度与裸藻门丰度呈正相关, 而与其他各门藻丰度呈负相关.

基于生物量,主成分轴 1 和轴 2 特征值分别是 0.339 和 0.040 , 即前 2 个轴共解释了 $37.9 \%$ 的浮游植物各 


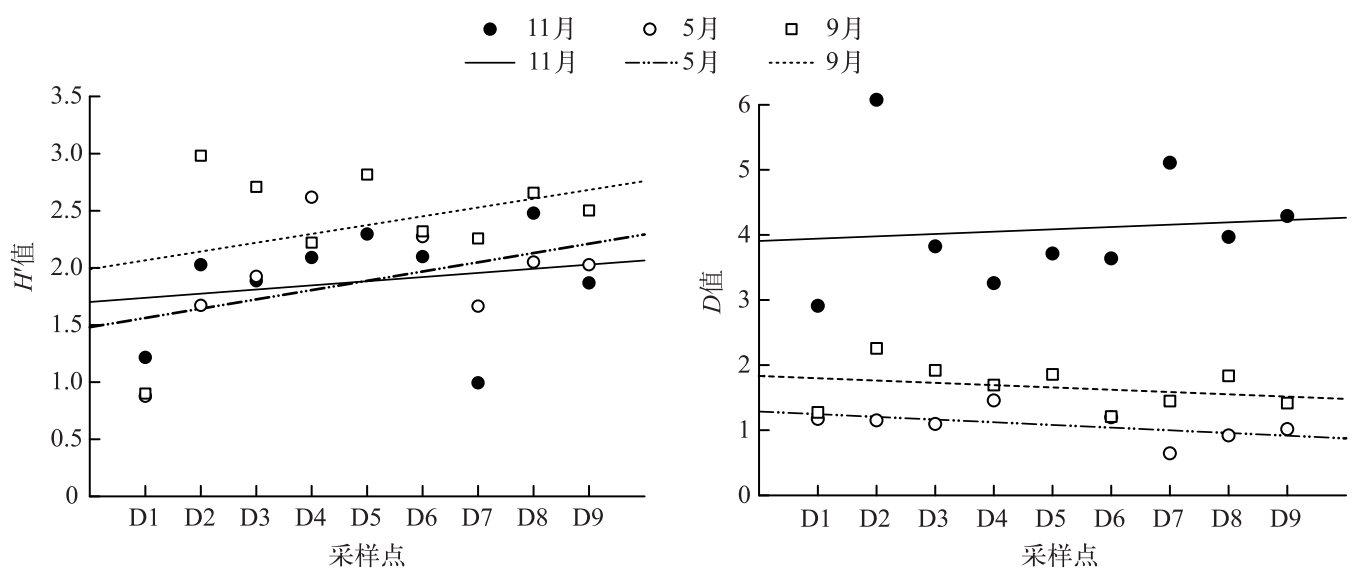

图 5 大九湖湿地不同子湖浮游植物多样性指数变化及沿水流方向的变化趋势

Fig.5 Variations of phytoplankton diversity indexes among different sub-lakes in

Daijiuhu wetland and trend analysis along water flow direction

门的生物量变化 (图 6b). 主成分轴 1 和轴 2 的物种与环境因子相关性分别为 $66.9 \%$ 和 $59.3 \%, 2$ 轴累计百分 比变化率为 $95.6 \%$, 表明前 2 个轴的物种与环境因子相关性高. RDA 蒙特卡罗检验前向选择检验表明, TP 浓度和 WT 对浮游植物生物量变化有显著影响 (图 6b). 这 2 个变量共解释了 $27.0 \%$ (分别为 $11.0 \%$ 和 $16.0 \%$ ) (图 6b). TP 浓度与金藻门生物量呈负相关, 而与其他各门藻类呈正相关; 而 WT 与金藻和硅藻类呈 负相关,而与其他各门藻类呈负相关.

\section{3 讨论}

\section{1 水质和浮游植物指标对水体营养状态的指示}

浮游植物群落受水体中营养盐, 特别是 TN、TP 浓度的影响 ${ }^{[29-30]}$, 浮游植物群落的种类组成及多样性能 够反映水体的富营养化程度 ${ }^{[6]}$, 但浮游植物的生长还受其他环境因子影响, 因此单一的浮游植物评价方法 不够全面, 本研究结合水质指标和浮游植物来评价大九湖湿地水体营养状况, 从结果上看二者是一致的. 大 九湖湿地 9 个子湖水质主要处于《地表水环境质量标准》(GB 3838-2002) III IV 类水之间, 主要超标污染 物为 $\mathrm{TN} 、 \mathrm{TP}$ 和 $\mathrm{COD}_{\mathrm{Mn}}$, 结合综合营养状态指数评价, 指示水体处于中营养一轻度富营养化水平之间. 浮游植 物优势种和多样性分析结果也显示在 3 次采样期间大九湖湿地水体属于中污染水体. 此外, 大九湖水体各 理化因子和浮游植物丰度等指标沿水流方向呈下降趋势 (图 2), 表明水质沿水流方向得到一定程度的净化.

本研究中, 11 月浮游植物优势种以硅藻和绿藻为主, 5 月以绿藻和蓝藻为主, 而 9 月以蓝藻和绿藻为主. Sommer 等 ${ }^{[31]}$ 认为浮游植物的演替规律大致为: 冬、春季以隐藻和硅藻为主, 夏季绿藻占优, 而到夏末秋初蓝 藻占优势, 秋季则硅藻再次占优势. Wang 等 ${ }^{[29]}$ 研究也表明, 在未污染的天然淡水水体中, 浮游植物春、秋季 以喜低温的硅藻、金藻为主, 夏季以喜高温的蓝藻、绿藻为主, 冬季浮游植物种类和数量均较少. 本研究中浮 游植物演替规律与上述结果类似, 优势种演替趋势为硅藻-绿藻-蓝藻, 但浮游植物种类主要为 $\alpha$-中污带或 $\beta$-中污染指示种. 此外, 9 月检测到的浮游植物优势种之一为拟柱狍藻, 拟柱狍藻由于产毒而对水生态安全 和人类健康造成威胁 ${ }^{[32]}$, 目前在饮用水源地监测中被重点关注 ${ }^{[33]}$.

从浮游植物丰度指标来看, 小于 $30 \times 10^{4} \mathrm{cells} / \mathrm{L}$ 时, 水体为贫营养型; 在 $30 \times 10^{4} \sim 100 \times 10^{4} \mathrm{cells} / \mathrm{L}$ 之间 时, 水体为中营养型; 大于 $100 \times 10^{4} \mathrm{cells} / \mathrm{L}$ 时, 水体为富营养型 ${ }^{[22]}$; 从浮游植物生物量指标来看, 小于 $1 \mathrm{mg} / \mathrm{L}$ 时, 水体为贫营养型; 在 $1 \sim 5 \mathrm{mg} / \mathrm{L}$ 之间时, 水体为中营养型; 在 $5 \sim 10 \mathrm{mg} / \mathrm{L}$ 之间时, 水体为富营养型 ${ }^{[34]}$. 本 研究中, 3 个季节水体浮游植物丰度和生物量均较高 (图 3), 基于上述丰度和生物量评价标准, 大九湖湿地 处于中营养一富营养水平, 但丰度和生物量评价结果存在差异, 原因可能是藻类生物量变化趋势不仅与数量 有关, 还与细胞大小有关. 有研究表明, 浮游植物的丰度特征不能客观地反映营养状态, 相比而言, 生物量更 

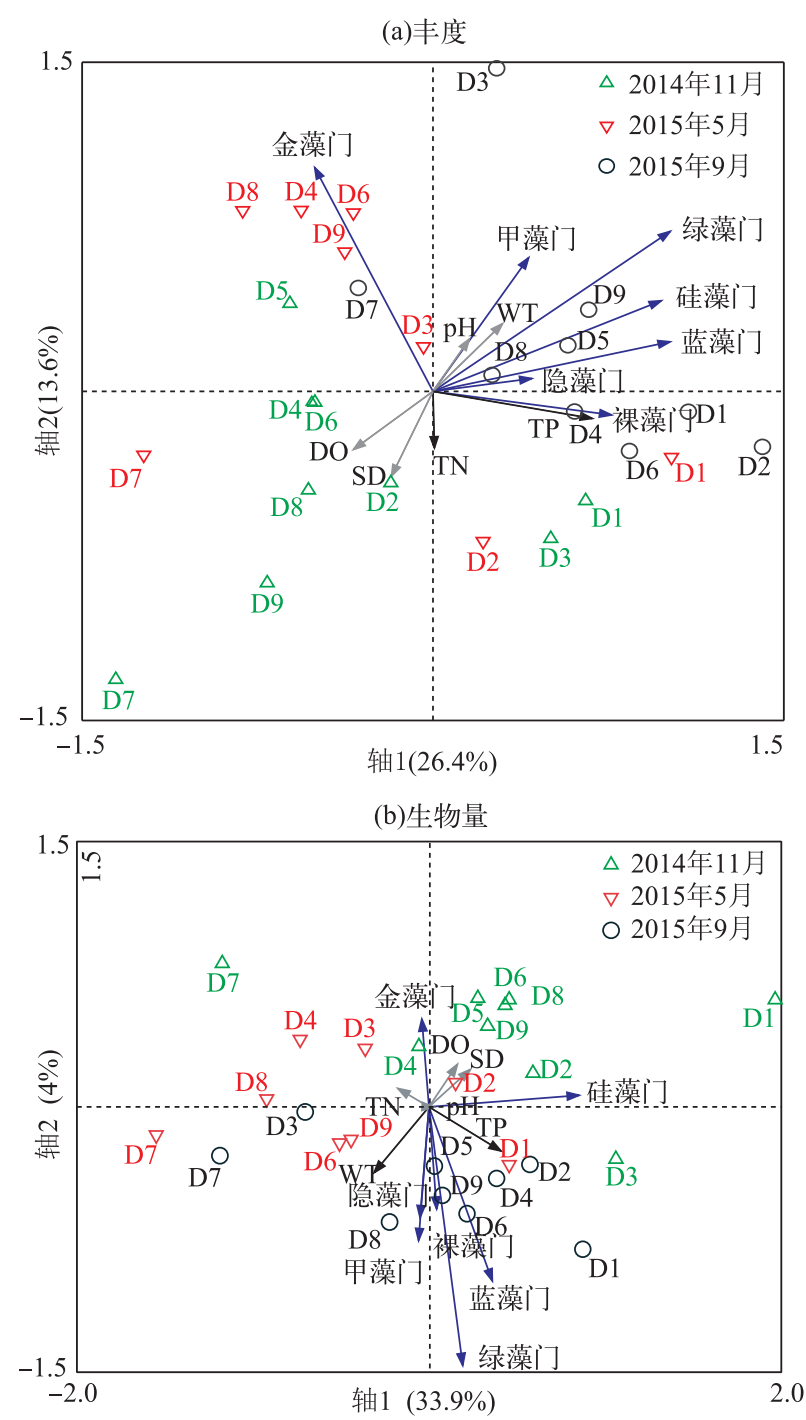

图 6 大九湖浮游植物、环境变量和采样点的圥余分析 (RDA) 三元图

(D1 D9 分别代表大九湖湿地 9 个子湖; 黑线为显著性环境变量,灰线为非显著性环境变量)

Fig.6 Redundancy analysis triplot ( sites, abundance and biomass of phytoplankton and environmental variables)

in Dajiuhu wetland (D1 to D9 indicate nine sub-lakes; Variables found

to be significant by forward selection are shown with bold arrows)

能可靠地反映水质的营养状态 ${ }^{[25,35]}$. Shannon-Wiener 指数和 Margalef 指数在 5 月和 11 月结果一致, 水质处 于 $\alpha$-中污染, 而在 11 月时前者为 $\alpha$-中污染, 后者为寡污染. 可能原因 Margalef 多样性指数反映的是浮游植 物种类数与环境之间的关系, 由于 Margalef 多样性指数只考虑了种类数和个体数量的关系, 而忽略了个体数 量在各种间分配的状况, 导致其评价结果与其他参数存在一定差异 ${ }^{[25]}$. 本研究尽管在浮游植物指标评价上 存在少量差异,但整体评价结果一致.

\section{2 环境因子对浮游植物的影响}

$\mathrm{RDA}$ 分析结果表明磷和氮是影响大九湖湿地浮游植物丰度和生物量的重要营养要素, 其中 TP 浓度对 浮游植物丰度和生物均有显著影响 (图 6). 大量的研究表明磷或氮往往是浮游植物生长和分布的限制因 
子 $^{[30]}$, 营养盐是浮游植物存活的必要条件, 浮游植物的物种多样性、丰度和生物量与营养盐的组成和浓度是 密不可分的. 在 RDA 图中, 除金藻外, 其他各门藻类丰度和生物量均与 TP 箭头方向一致, 即 TP 浓度较高的 区域, 这些区域主要是 9 月采样点和其他 2 个月的 D1 和 D2 采样点, 该区域磷浓度相对高, 有利于浮游植物 的生长. 在研究期间, 在大九湖湿地周边的土地已经退耕还林还草, 农业面源污染很少, 其人为干扰主要是 大九湖镇的居民和游客带来的生活废水. 旅游主要从 5 月开始, 7-10 月是旅游旺季, 10 月黄金周后游客变 少, 其中干扰最严重的区域就是位于大九湖镇旁边的 D1 和 D2 号湖. 本研究中沿湿地的水流方向, 营养盐呈 下降趋势也验证了外源污染输人集中在 D1 和 D2 等子湖 (图 2). 而对于氮的作用, RDA 分析结果表明 TN 浓度对浮游植物丰度也有显著影响, 但 TN 浓度与藻类丰度 (除裸藻外) 呈负相关. 氮的来源除了生活废水 外, 有研究表明大气沉降是也是水体氮的最主要来源 ${ }^{[36]}$, 降雨增加湿地接收来自大气沉降的氮, 提高水体中 氮浓度, 因此氮的影响更复杂.

本研究中, 大九湖 11 月 TN/TP 比均值和范围为 34.1( 12.0 81.4), 5 月 TN/TP 比均值和范围为 39 (18.3 93.0), 9 月 TN/TP 比均值和范围为 17.2( 9.3 31). Abell 等 ${ }^{[37]}$ 认为 TN/TP 比 $<7$ 时 (以质量计) 是氮 限制, 也有一些研究者给出不同的比例 ${ }^{[38]}$. Downing 等 ${ }^{[30,39]}$ 认为, 氮限制或磷限制主要取决于磷的水平, 当 $\mathrm{TP}>0.03 \mathrm{mg} / \mathrm{L}$ 时, TN 与 Chl. a 浓度的变化显著相关. 而在针对高山湖泊的研究发现, 氮和磷协同影响浮游 植物的变化 ${ }^{[40]}$, 尤其是在一些塞营养的高山湖泊中 ${ }^{[41-43]}$. 在美国科罗拉多山的 8 个湖泊中, 有 3 个是氮限 制, 1 个磷限制, 其他 4 个是氮、磷共同作用 ${ }^{[44]}$, 而在美国瑞尼尔山的 9 个湖泊中主要是氮限制或氮、磷共限 制 ${ }^{[45]}$. 在大九湖同一类似纬度的平原湖泊太湖水体中, 氮、磷浓度存在较大的季节变化, 氮在春季和冬季浓 度较高, 而夏季和秋季浓度较低; 磷浓度的季节变化与氮相反, 春季和冬季浓度较低, 而夏季和秋季相对较 高; 对应于氮、磷浓度的季节变化, N/P 比值也呈现较大的季节变化, 冬季和春季 TN/TP 比值变化范围为 $30 \sim 80$, TDN/TDP 比值变化范围为 $52 \sim 212$, 而夏季比值均降到小于 $20^{[46]}$, 表明氮和磷会同时显著影响浮游 植物的变化或不同季节间氮磷交替影响浮游植物的变化 ${ }^{[47-48]}$. 而在黑龙江扎龙湿地, TN 和 TP 浓度对黑龙 江扎龙湿地浮游植物生长和属种分布影响较大 ${ }^{[49]}$. 在大九湖湿地, TN/TP 比在 3 个季节均较高, 结合 RDA 分析结果和营养盐指标, 表明大九湖湿地以磷限制为主.

温度是最重要的影响浮游植物的环境因子之一 ${ }^{[50]}$, 温度不仅影响浮游植物生长率, 而且影响其群落结 构变化 ${ }^{[51-52]}$. 在大九湖湿地, 水温是影响浮游植物生物量季节变化的最重要环境因子, 它解释了 $16 \%$ 的浮游 植物生物量变化. 从 RDA 图上可以看出, 水温增高, 隐藻、甲藻、裸藻、绿藻和蓝藻丰度和生物量均增高, 而 金藻和硅藻生物量降低. 通常, 金藻和硅藻喜低温, 温度较低时为优势种, 而蓝藻、绿藻喜欢高温, 主要出现 在温度较高的季节 ${ }^{[53-56]}$. 一般来说, 蓝藻、绿藻的生长需要较高的温度, 其最适温度为 $25 \sim 35^{\circ} \mathrm{C}^{[57]}, 15^{\circ} \mathrm{C}$ 以 下生长受到限制 ${ }^{[58]}$. 本研究结果与以上研究结果一致.

从图 6 可以看出, 不同采样点在季节上有明显区别, 且在同一季节不同采样点的浮游植物丰度和生物 量也差别较大. 研究中监测到的环境因子对浮游植物丰度和生物量分别解释了 $40 \%$ 和 38\%, 表明还有其他 大量的环境因子对浮游植物丰度和生物量变化产生重要影响. 浮游植物丰度和生物量以及群落结构的变化 不仅受氮、磷等营养盐和温度的影响 ${ }^{[59]}$, 还受到流域的土地利用 ${ }^{[60]}$ 、鱼类的丰度和群落组成 ${ }^{[61]}$ 、太阳辐 射 ${ }^{[52]}$ 、水生植物和水流流速的影响 ${ }^{\left[{ }^{[62-63]}\right.}$. 本研究中, 大九湖湿地九个子湖水生动物结构差异可能对浮游植 物的种类丰度和生物量产生影响, 例如 2014 年 11 月调查发现, 尽管大九湖湿地鲫鱼是绝对优势种 ${ }^{[18]}$, 但其 中 D1 子湖鲫和镜鲤均较多, D2 和 D4 子湖以鲢和镜鲤为主, D3、D5 和 D9 子湖以鲫为主, D6 子湖以鲢和鲫 为主, D7 和 D8 子湖以小型的棒花鱼为主. 大量研究表明, 浮游生物食性鱼类的捕食是调节浮游动物丰度和 种类的主要因子之一 ${ }^{[64]}$, 从而间接地影响了水体的浮游植物和理化条件. 然而, 底栖鱼类如鲤, 可能会引起 沉积物再悬浮, 增加沉积物中营养盐的释放, 导致透明度降低 ${ }^{[65]}$, 最终也影响浮游植物生长条件. 此外, 调 查中发现 D7 有较多河蚌, 水质清澈见底, D7 点在 RDA 图也和其他点位存在差异 (图 6), 表明河蚌的存在可 能通过滤食影响了浮游植物群落结构, 起到控藻和净化水质的作用 ${ }^{[66]}$. 因此, 大九湖湿地各子湖鱼类优势 种群的差异以及底栖动物的差异可能也是影响浮游植物种群结构异质性的原因之一.

\section{4 结论}

1) 综合理化指标、营养状态指数及浮游植物优势种指示法、浮游植物多样性指数等多种调查方法, 结果 
表明采样期间大九湖湿地水质营养程度处于中营养-轻度富营养水平. 总的来说, 利用理化指标和浮游植物 指标对大九湖湿地水质营养状况分析得到的结果基本一致.

2) 大九湖湿地水体各理化指标和综合营养状态指数沿水流方向呈下降趋势, 影响浮游植物种群丰度和 生物量的主要环境因子除了季节变化外主要就是磷. 磷浓度增加与蓝藻和绿藻的丰度和生物量呈正相关, 表明外源磷输人的控制应引起重视.

\section{5 参考文献}

[ 1 ] Padisák J, Borics G, Grigorszky I et al. Use of phytoplankton assemblages for monitoring ecological status of lakes within the Water Framework Directive: The assemblage index. Hydrobiologia, 2006, 553(1) : 1-14. DOI: 10.1007/s10750-0051393-9.

[ 2 ] Marchetto A, Padedda BM, Mariani MA et al. A numerical index for evaluating phytoplankton response to changes in nutrient levels in deep mediterranean reservoirs. Journal of Limnology, 2009, 68(1): 106-121. DOI: 10.4081/jlimnol. 2009.106.

[ 3 ] Katsiapi M, Moustaka-Gouni M, Sommer U. Assessing ecological water quality of freshwaters: PhyCoI-A new phytoplankton community Index. Ecological Informatics, 2016, 31: 22-29. DOI: 10.1016/j.ecoinf.2015.11.004.

[ 4 ] Huszar VLM, Caraco N. The relationship between phytoplankton composition and physical-chemical variables: A comparison of taxonomic and morphological-functional approaches in six temperate lakes. Freshwater Biology, 1998, 40(4) : 679696. DOI: 10.1046/j.1365-2427.1998.d01-656.x.

[ 5 ] Ptacnik R, Solimini AG, Brettum P. Performance of a new phytoplankton composition metric along a eutrophication gradient in Nordic lakes. Hydrobiologia, 2009, 633(1) : 75-82. DOI: 10.1007/s10750-009-9870-1.

[ 6 ] Fott B ed. Phycology. Luo DA translated. Shanghai: Shanghai Scientific and Technical Publishers, 1980: 422-428. [B. 福 迪 (捷克). 藻类学. 罗迪安译. 上海: 上海科学技术出版社, 1980: 422-428.]

[ 7 ] $\mathrm{O}^{\prime}$ Neil JM, Davis TW, Burford MA et al. The rise of harmful cyanobacteria blooms: the potential roles of eutrophication and climate change. Harmful Algae, 2013, 14(1) : 313-334. DOI:10.1016/j.hal.2011.10.027.

[ 8 ] WHO, World Health Organization. Guidelines for drinking-water quality. World Health Organization, 2004.

[ 9 ] EU WFD. Directive 2000/60/EC of the European Parliament and of the council of 23 October 2000 establishing a framework for community action in the field of water policy. Official Journal of European Communities, 2000, L327( 43) : 1-72.

[10] Katsiapi M, Moustaka-Gouni M, Michaloudi E et al. Phytoplankton and water quality in a mediterranean drinking-water reservoir (Marathonas Reservoir, Greece). Environmental Monitoring \& Assessment, 2011, 181(1-4) : 563-575. DOI: 10. 1007/s10661-010-1851-3.

[11] Sheng HY, Yao JZ, He JB et al. Phytoplankton community variationand relationship with environmental factors in Qingshanhu Reservoir, Zhejiang province. Resources and Environment in the Yangtze Basin, 2015, 24(6) : 978-986. DOI: 10. 11870/cjlyzyyhj201506012. [盛海燕, 姚佳玫, 何剑波等. 浙江青山水库浮游植物群落结构变化及与环境因子的关 系. 长江流域资源与环境, 2015, 24(6): 978-986.]

[12] Wang YH, Chen L, Niu Y et al. Spatio-temporal variation in phytoplankton community and its influencing factors in Danjiangkou Reservoir. J Lake Sci, 2016, 28 (5) : 1057-1065. DOI : 10.18307/2016.0516. [王英华, 陈雷, 牛远等. 丹江口 水库浮游植物时空变化特征. 湖泊科学, 2016, 28(5):1057-1065.]

[13] Du Y, Cai SM, Wang XL et al. Environment background and ecological restoration of the Dajiuhu subalpine wetland in mountain Shennongjia. Resources and Environment in the Yangtze Basin, 2008, 17(6): 915-919. [杜耘, 蔡述明, 王学 雷等. 神农架大九湖亚高山湿地环境背景与生态恢复. 长江流域资源与环境, 2008, 17 (6) : 915-919.]

[14] Jiang LZ, Wang XL, Li EH et al. A Study on the land use change of Dajiuhu wetland in mountain Shennongjia in response to ecological restoration. Journal of Huazhong Normal University: Nat Sci, 2013, 47(2) : 282-286. [姜刘志, 王学雷, 厉恩华等. 生态恢复前后神农架大九湖湿地土地利用变化研究. 华中师范大学学报: 自然科学版, 2013, 47(2) : 282-286.]

[15] Tan KJ, Zhou XQ, Zhang ZL. The development and protection of Dajiuhu wetland in mountain Shennongjia. Hubei Forestry Science and Technology, 2014, 43(1) : 52-55. [谭开甲, 周晓庆, 张志麒. 神农架大九湖湿地开发与保护. 湖北林业 科技, 2014, 43(1): 52-55.] 
[16] Liu HP, Tang XC, Sun DH et al. Palynofloras of the Dajiuhu basin in Shennongjia mountains during the last 12.5 ka. Acta Micropalaeontologica Sinica, 2001, 18(1) : 101-109. [刘会平, 唐晓春, 孙东怀等. 神农架大九湖 $12.5 \mathrm{ka} \mathrm{BP}$ 以来的 狍粉与植被序列. 微体古生物学报, 2001, 18(1): 101-109.]

[17] Li J, Zheng Z, Rachid C et al. Pollen-based environmental reconstruction around Dajiuhu Lake, Shennongjia Mountains since 40 ka BP. Acta Geographica Sinica, 2013, 68(1) : 69-81. DOI: 10.11821/xb201301009. [李杰, 郑卓, Rachid C 等. 神农架大九湖四万年以来的植被与气候变化. 地理学报, 2013, 68(1):69-81.]

[18] Li J, Liu MQ, Gao J et al. Fish species composition after ecological restoration in a Dajiuhu wetland. Ecological Science, 2017, 36(1) : 159-164. [李俊, 刘梅群, 高健等. 神农架大九湖湿地实施生态恢复工程后鱼类种类组成分析. 生态 科学, $2017,36(1): 159-164$.

[19] Ministry of Environmental Protection of the People's Republic of China, Editorial Board of Water and Wastewater Monitoring and Analysis Methods eds. Water and Wastewater Monitoring and Analysis Methods: 4th edition. Beijing: China Environmental Science Press, 2005. [ 国家环境保护总局《水和废水监测分析方法》编委会. 水和废水监测分析方法: 第 4 版. 北京: 中国环境科学出版社, 2005. ]

[20] Hu HJ, Wei YX eds. Chinese freshwater algae-System, classification and ecology. Beijing: Science Press, 2006. [胡鸿 均, 魏印心.中国淡水藻类——系统, 分类及生态. 北京: 科学出版社, 2006.]

[21] Zhang ZS, Huang XF eds. Research methods of freshwater plankton. Beijing: Science Press, 1995. [章宗涉, 黄祥飞. 淡 水浮游生物研究方法. 北京: 科学出版社, 1995.]

[22] Wang MC, Liu XQ. Evaluate method and classification standard on lake eutrophication. Environmental Monitoring in Chi$n a, 2002,18(5): 47-49$. [王明翠, 刘雪芹. 湖泊富营养化评价方法及分级标准. 中国环境监测, 2002, 18(5): 47-49.]

[23] The Ministry of Water Resources ofthe People's Republic of China. China Water Resource Bulletin. Beijing: China Water \& Power Press, 2005. [中华人民共和国水利部. 中国水资源公报. 北京: 中国水利水电出版社, 2005. ]

[24] Mcnaughton SJ. Relationships among Functional Properties of Californian Grassland. Nature, 1967, 216(5111) : 168-169. DOI: $10.1038 / 216168 \mathrm{~b} 0$.

[25] Wang JL, Liu DY, Gu BH et al. Environmental assessment of Lake Taiping (Anhui Province) based on a phytoplankton community analysis. J Lake Sci, 2014, 26(6) : 939-947. DOI: 10.18307/2014.0617. [王俊莉, 刘冬燕, 古滨河等. 基 于浮游植物群落的安徽太平湖水环境生态评价. 湖泊科学, 2014, 26(6) : 939-947.]

[26] Shannnon CE, Weaver W eds. The mathematical theory of communication. Urbana: University of Illinois Press, 1949: 213-216.

[27] Margalef DR ed. Inpersproctivesi marine biology ( A Buzzati Traversoed). California: University California Press, 1958: 323-347.

[28] Lepš J, Šmilauer P eds. Multivariate analysis of ecological data using CANOCO. London: Cambridge Univiversity Press, 2003.

[29] Wang XL, Lu YL, He GZ et al. Exploration of relationships between phytoplankton biomass and related environmental variables using multivariate statistical analysis in a eutrophic shallow lake: a 5-year study. Journal of Environmental Sciences, 2007, 19(8) : 920-927. DOI: 10.1016/S1001-0742(07)60152-1.

[30] Søndergaard M, Lauridsen TL, Johansson LS et al. Nitrogen or phosphorus limitation in lakes and its impact on phytoplankton biomass and submerged macrophyte cover. Hydrobiologia, 2017, 795( 1 ) : 35-48.

[31] Sommer U, Maciej GZ, Lampert M et al. The PEG model of seasonal succession of planktonic events in freshwaters. Hydrobiologia, 1986, 106(4) : 433-471.

[32] Su XM, Xue QJ, Cao Q et al. Advances and prospects in eco-toxicity of cylindrospermopsin. Asian Journal of Ecotoxicolo$g y, 2016,12$ (1) : 64-72. DOI: 10.7524/AJE.1673-5897.20160712001. [苏小妹, 薛庆举, 操庆等. 拟柱孢藻毒素生 态毒性的研究进展和展望. 生态毒理学报, 2016, 12(1): 64-72.]

[33] Zhao L, Lei NM, Peng L et al. Seasonal dynamic and driving factors of Cylindrospermopsis raciborskii in Zhenhai Reservoir, Guangdong Province. J Lake Sci, 2017, 29(1) : 193-199. DOI: 10.18307/2017.0121. [赵莉, 雷腊梅, 彭亮等. 广东省镇海水库拟柱狍藻 (Cylindrospermopsis raciborskii) 的季节动态及驱动因子分析. 湖泊科学, 2017, 29(1): 193-199.]

[34] Shen YF, Zhang ZS, Gong XJ et al eds. The new detection technique on miniature organisms. Beijing: China Architecture 
Industry Press, 1990. [沈暳芬, 章宗涉, 龚循矩等. 微型生物监测新技术. 北京: 中国建筑出版社, 1990. ]

[35] Zhao XF, Yu J, Ge JH et al. Study on the phytoplankton and water quality of Jihongtan Reservoir in Qingdao. Acta Hydrobiologica Sinica, 2005, 29(6) : 639-644. [赵先富, 于军, 葛建华等. 青岛棘洪滩水库浮游藻类状况及水质评价. 水 生生物学报, 2005, 29(6) : 639-644.]

[36] Pitkänen H, Lehtoranta J, Räike A. Internal nutrient fluxes counteract decreases in external load: the case of the estuarial eastern gulf of Finland, Baltic Sea. Ambio, 2001, 30(4/5) : 195-201. DOI: 10.1579/0044-7447-30.4.195.

[37] Abell J, Özkundakci D, Hamilton D. Nitrogen and phosphorus limitation of phytoplankton growth in New Zealand lakes: implications for eutrophication control. Ecosystems, 2010, 13(7) : 966-977. DOI: 10.1007/s10021-010-9367-9.

[38] Guildford SJ, Hecky RE. Total nitrogen, total phosphorus, and nutrient limitation in lakes and oceans: is there a common relationship? Limnology and Oceanography, 2000, 45(6) : 1213-1223. DOI: 10.4319/lo.2000.45.6.1213.

[39] Downing JA, McCauley E. The nitrogen: phosphorus relationship in lakes. Limnology and Oceanography, 1992, 37 (5) : 936-945. DOI: 10.4319/lo.1992.37.5.0936.

[40] Scott JT, McCarthy MJ. Nitrogen fixation may not balance the nitrogen pool in lakes over timescales relevant to eutrophication management. Limnology and Oceanography, 2010, 55(3) : 1265-1270. DOI: 10.4319/lo.2010.55.3.1265.

[41] Dodds WK, Johnson KR, Priscu JC. Simultaneous nitrogen and phosphorus deficiency in natural phytoplankton assemblages : theory, empirical evidence and implications for lake management. Lake and Reservoir Management, 1989, 5(1) : 2126. DOI: $10.1080 / 07438148909354677$.

[42] Elser JJ, Marzolf ER, Goldman CR. Phosphorus and nitrogen limitation of phytoplankton growth in the freshwaters of north America: A review and critique of experimental enrichments. Canadian Journal of Fisheries \& Aquatic Sciences, 1990,47 (7) : 1468-1477. DOI: 10.1139/f90-165.

[43] Lafrancois BM, Nydick KR, Caruso B. Influence of nitrogen on phytoplankton biomass and community composition in fifteen Snowy Range Lakes (Wyoming U.S. A.). Artic Antarctic and Alpine Research, 2003, 35(4) : 499-508. DOI: 10. 1139/f04-085

[44] Morris DP, Lewis WM. Phytoplankton nutrient limitation in Colorado mountain lakes. Freshwater Biology, 1988, 20(3): 315-327. DOI: $10.1111 /$ j.1365-2427.1988.tb00457.x.

[45] Williams JJ, Beutel M, Nurse A et al. Phytoplankton responses to nitrogen enrichment in Pacific Northwest, USA Mountain Lakes. Hydrobiologia, 2016, 776 (1) : 261-276. DOI: 10.1007/s10750-016-2758-y.

[46] Xu H, Paerl HW, Qin B et al. Nitrogen and phosphorus inputs control phytoplankton growth in eutrophic Lake Taihu, China. Limnology and Oceanography, 2010, 55(1) : 420-432. DOI: 10.4319/lo.2010.55.1.0420.

[47] Dolman AM, Mischke U, Wiedner C. Lake-type-specific seasonal patterns of nutrient limitation in German lakes, with target nitrogen and phosphorus concentrations for good ecological status. Freshwater Biology, 2016, 61(4) : 444-456. DOI: $10.1111 /$ fwb. 12718 .

[48] Mischler JA, Taylor PG, Townsend AR. Nitrogen limitation on pond ecosystems on the plains of eastern Colorado. PloS One, 2014, 9(5) : e95757. DOI: 10.1371/journal.pone.0095757.

[49] Zhang NN, Liu YX, Zang SY. Relationships between phytoplankton community in different functional regions and environmental factors in Zhalong Wetland, Heilongjiang Province. J Lake Sci, 2016, 2016, 28(3) : 554-565. DOI: 10.18307/ 2016.0311. [张因囡, 刘宜金金, 藏淑英. 黑龙江扎龙湿地不同功能区浮游植物群落与环境因子的关系. 湖泊科学, $2016,28(3)$ : 554-565.]

[50] Rhee GY, Gotham IJ. The effect of environmental factors on phytoplankton growth: temperature and the interactions of temperature with nutrient limitation. Limnology and Oceanography, 1981, 26(4): 635-648. DOI: 10.4319/lo. 1981.26. 4.0635 .

[51] Elliott JA, Jones ID, Thackeray SJ. Testing the sensitivity of phytoplankton communities to changes in water temperature and nutrient load, in a temperate lake. Hydrobiologia, 2006, 559(1) :401-411. DOI: 10.1007/s10750-005-1233-y.

[52] Edwards KF, Thomas MK, Klausmeier CA et al. Phytoplankton growth and the interaction of light and temperature: a synthesis at the species and community level. Limnology \& Oceanography, 2016, 61 (4) : 1232-1244. DOI: 10. 1002/ lno.10282.

[53] Dong ZW, Zhao XY, Chen LH et al. Phytoplankton community changes during wetland restoration in Jinghe Estuary, Lake Ebinur, Xinjiang. J Lake Sci, 2011, 23(3) : 395-400. DOI:10.18307/2011.0312. [董正武, 赵晓英, 陈丽华等. 新疆 
艾比湖精河人湖口退化湿地恢复过程中浮游植物群落的变化. 湖泊科学, 2011, 23(3) : 395-400.]

[54] Chen LJ, Wu ZC, Hu ZJ et al. Phytoplankton community structure in Mingzhu Lake of Chongming Island, Shanghai. Chinese Journal of Applied Ecology, 2011, 22(6) : 1599-1605. [陈立婧, 吴竹臣, 胡忠军等. 上海崇明岛明珠湖浮游植 物群落结构. 应用生态学报, 2011, 22(6): 1599-1605.]

[55] Chen Q, Zhang C, Recknagel F et al. Adaptation and multiple parameter optimization of the simulation model SALMO as prerequisite for scenario analysis on a shallow eutrophic Lake. Ecological Modelling, 2014, 273(7) : 109-116. DOI: 10. 1016/j.ecolmodel.2013.11.006.

[56] Wu AQ, Guo N, Qin XB. Seasonal variation of phytoplankton functional groups and their relationship with environmental factors in a typical cold regions wetland. Acta Scientiae Circumstantiate, 2015, 35(5) : 1341-1349. DOI: 10.13671/j. hjkxxb.2014.0729. [武安泉, 郭宁, 覃雪波. 寒区典型湿地浮游植物功能群季节变化及其与环境因子关系. 环境科 学学报, 2015, 35(5):1341-1349.]

[57] Nalewajko C, Murphy TP. Effects of temperature, and availability of nitrogen and phosphorus on the abundance of Anabae$n a$ and Microcystis in Lake Biwa, Japan: An experimental approach. Limnology, 2001, 2(1): 45-48. DOI: 10. 1007/s102010170015.

[58] Robarts RD, Zohary T. Temperature effects on photosynthetic capacity, respiration, and growth rates of bloom-forming cyanobacteria. New Zealand Journal of Marine and Freshwater Research, 1987, 21(3) : 391-399. DOI: 10.1080/00288330. 1987.9516235 .

[59] Jeppesen E, Søndergaard M, Jensen JP et al. Lake responses to reduced nutrient loading-An analysis of contemporary long-term data from 35 case studies. Freshwater Biology, 2005, 50(10) : 1747-1771. DOI: 10.1111/j.1365-2427.2005. 01415.x.

[60] Crosbie B, Chow-Fraser P. Percentage land use in the watershed determines the water and sediment quality of 22 marshes in the Great Lakes basin. Canadian Journal of Fisheries and Aquatic Sciences, 1999, 56(10) : 1781-1791. DOI: 10.1139/ f99-109.

[61] Potthoff AJ, Herwig BR, Hanson MA et al. Cascading food-web effects of piscivore introductions in shallow lakes. Journal of Applied Ecology, 2008, 45(4) : 1170-1179. DOI: 10.1111/j.1365-2664.2008.01493.x.

[62] Xiao X, Lou LP, Li H et al. Algal controllability of allelopathically active submerged macrophytes. Chinese Journal of Applied Ecology , 2009, 20(3) : 705-712. [ 肖溪, 楼莉萍, 李华等. 沉水植物化感作用控藻能力评述. 应用生态学报, 2009,20 (3):705-712.]

[63] Zhang W, Wang WD, Wang LQ et al. Phytoplankton community structure in Shijiuyang constructed wetland of Jiaxing. Zhejiang Province of East China in winter. Chinese Journal of Applied Ecology, 2011, 22(9): 2431-2437. [张玮, 王为 东, 王丽卿等. 嘉兴石臼漾湿地冬季浮游植物群落结构特征. 应用生态学报, 2011, 22(9): 2431-2437.]

[64] Jeppesen E, Lauridsen TL, Mitchell SF et al. Trophic structure in the pelagial of 25 shallow New Zealand lakes: changes along nutrient and fish gradients. Journal of Plankton Research, 2000, 22 ( 5) : 951-968. DOI: 10.1093/plankt/22.5.951.

[65] Scheffer M, Portielje R, Zambrano L. Fish facilitate wave resuspension of sediment. Limnology and Oceanography, 2003, 48(5) : 1920-1926. DOI: $10.4319 /$ lo.2003.48.5.1920.

[66] Pan JL, Tang JQ, Xu ZK et al. Study on the effects of large mollusks on alga control and water quality at Meiliang gulf in Lake Taihu. Transactions of Oceanology and Limnology, 2007, (2) : 69-79. [潘建林, 徐在宽, 唐建清等. 湖泊大型贝 类控藻与净化水质的研究. 海洋湖沼通报, 2007, (2) : 69-79.] 